\title{
Tumor-Suppressive and Tumor-Promoting Role of Tgf- $\beta$ in Hepatocellular Carcinoma
}

\author{
Somyoth Sridurongrit ${ }^{1}$ \\ ${ }^{1}$ Department of Anatomy, Faculty of Science, Mahidol University, Bangkok, Thailand \\ Correspondence: Somyoth Sridurongrit, Department of Anatomy, Faculty of Science, Mahidol University, \\ Bangkok, Thailand. E-mail: somyoth.sri@mahidol.ac.th
}

Received: December 6, 2016

Accepted: December 22, 2016 Online Published: December 31, 2016

doi:10.5539/ijb.v9n1p41

URL: http://dx.doi.org/10.5539/ijb.v9n1p41

\begin{abstract}
Tgf- $\beta$ is a pleiotropic cytokine with diverse functions on hepatic cells. The well-known function of Tgf- $\beta$ in pathogenesis of liver disease is to stimulate liver fibrosis that often precedes the onset of liver cancer. While Tgf- $\beta$-mediated fibrosis seems to make liver more prone to the development of liver cancer, Tgf- $\beta$ suppresses initial malignant transformation of hepatic cells thru regulation of proliferation and apoptosis. On the other hand, Tgf- $\beta$ has shown to act as an inducer of tumor development thru enhancement of metastatic process. Additionally, it has been shown that Tgf- $\beta$ signaling in hepatocytes promotes hepatocarcinogenesis caused by certain genetic conditions. This review highlights observations that have improved an understanding of how Tgf- $\beta$ contributes to the development of hepatocellular carcinoma.
\end{abstract}

Keywords: Tgf- $\beta$, fibrosis, chronic liver disease, Hepatocellular Carcinoma

\section{Introduction}

Hepatocellular carcinoma (HCC) is among the most common cancer that causes increasing morbidity and mortality every year (Ferlay et al., 2010; Nordenstedt, White, \& El-Serag, 2010). HCC frequently develops in patient with clinical history of chronic liver injury (Bissell, 2001). There are several major risk factors for HCC. Hepatitis B (HBV) and Hepatitis C Virus (HCV) infection represents the major risk factor for HCC worldwide whereas alcoholic-induced liver injury, nonalcoholic steatohepatitis (NASH), autoimmune disorders are also considered important contributors (Ferlay et al., 2010; Nordenstedt et al., 2010).Other risk factors include genetically determined disorders, such as cystic fibrosis (O'Donnell, Ryan, Hayes, Fennelly, \& Gibney, 2009), hereditary hemochromatosis (Kowdley, 2004) and Wilson's disease (Kumagi et al., 2004).

When liver is subjected to the pathological conditions, compromised hepatocytes trigger reparative response that consists of fibrosis and inflammation. Chronic injury in diseased livers leads to increased number of reactive cells such as fibrogenic fibroblasts and inflammatory cells. These reactive cells produce various types of potent tropic factor and cytokine that contributes to a malignant transformation of hepatocyte into HCC. Among factors known to be involved in HCC development, Transforming growth factor (Tgf- $\beta$ ) has shown to play diverse functions in liver carcinogenesis. The role of Tgf- $\beta$ appears to favor HCC development in pre-cancerous stage since it promote the accumulation of myofibroblasts and inflammation that are source of inducing factors for malignant transformation. On the other hand, Tgf- $\beta$ has shown to regulate proliferation and apoptosis of pre-malignant hepatocyte and, therefore, inhibit hepatocarcinogenesis. Interestingly, it has been shown that Tgf- $\beta$ accelerates HCC development caused by specific gene mutations. This review focuses on findings that shed light on mechanism in which Tgf- $\beta$ influences tumorigenesis of HCC.

\section{Overview of Tgf- $\beta$ Signaling}

Tgf- $\beta$ belongs to the superfamily of cytokines that include Bone Morphogenetic Protein (BMP), growth differentiation factor (GDF), anti-mullerian hormone (AMH), myostain, activin and inhibin (Piek, Heldin, \& Ten Dijke, 1999). Three highly homologous Tgf- $\beta$ isoforms such as Tgf- $\beta 1$, Tgf- $\beta 2$, Tgf- $\beta 3$ have been identified in mammalian cells. Although all three isoforms transduce similar signaling transduction pathway, They were shown to have quite different biological response (Massague \& Chen, 2000). Tgf- $\beta$ s initiate the signaling transduction via two types of cell surface receptors type II and type I that signal thru cytoplasmic serine/theronine kinase domain (Attisano \& Wrana, 2002). Upon ligand binding, type II receptors (T $\beta$ RII) recruits type I receptor (T $\beta$ RI, activin 


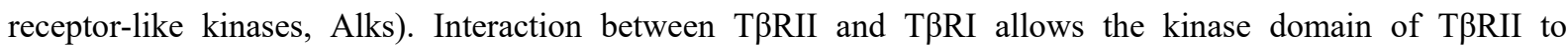
phosphorylate Alks in a glycine- and serine-rich juxtamembrane region called GS domain which is an essential step that initiate downstream signaling cascades. Phosphorylated Alks then activate the receptor-activated Smads (R-Smads) that allows them to bind to the common Smads (Co-Smads). R-Smad/Co-Smad complex subsequently translocates into nucleus where it acts as transcription factors and regulate expression of many target genes (Heldin, Miyazono, \& ten Dijke, 1997; Massague \& Chen, 2000).

Mammalian cells express five type II receptors (BMPRII, ActRII, ActRIIB, T $\beta$ RII and AMHR), seven type I receptors (Alk1-Alk7), five R-Smads (Smad1, Smad2, Smad3, Smad5 and Smad8), one Co-Smad (Smad4), and two inhibitory (I)-Smads (Smad6 and Smad7). Alk1, Alk2, Alk3 and Alk6 phosphorylate Smad1, Smad5 and Smad8 whereas Alk4, Alk5 and Alk7 activate Smad2 and Smad3 (Derynck \& Zhang, 2003; Piek et al., 1999; ten Dijke \& Hill, 2004). While Tgf- $\beta$ signals T $\beta$ RII-Alk5-Smad $2 / 3$ pathway in most cells, previous studies have shown that Tgf- $\beta$ initiates Alk1-Smad1/5 signaling pathway in addition to activation of Alk5-Smad2/3 cascade in certain cell type such as endothelial cells and Hepatic Stellate Cells (Goumans et al., 2003; Wiercinska et al., 2006).

Several line of evidence has shown that the transduction of Tgf- $\beta$ signaling leads to increased expression of I-Smad that enables inhibition of Tgf- $\beta$-mediated response (Chen, Huang, Morinelli, Trojanowska, \& Paul, 2002; Nakao et al., 1997; von Gersdorff et al., 2000). There are many way that Tgf- $\beta$ signaling can be downregulated by I-Smad. Smad 6/7 is able to block recruitment of Alks to Tgf- $\beta$-T $\beta$ RII complex and suppress phosphorylation of Smad2/3(Y. Shi \& Massague, 2003; Zhao, Shi, Chen, \& Warburton, 2000). Smad7 also promote degradation of type II-type I receptor complexes by recruiting E3-ubiquitin ligase (Ebisawa et al., 2001). Additionally, Smad7 was shown to mediate dephosphorylation and inactivation of Alk5 thru the recruitment of GADD34 complex and the catalytic subunit of protein phosphatase 1 (W. Shi et al., 2004).

\section{Tgf- $\beta$ in Pre-Cancerous Stage of HCC}

The role of Tgf- $\beta$ s in organ fibrosis and collagen synthesis was identified more than 20 years ago (Czaja et al., 1989). The increased expression of Tgf- $\beta$ family members are often found in regions of extracellular matrix (ECM) deposition in many fibrotic diseases (Branton \& Kopp, 1999). Tgf- $\beta$ s have been implicated as an important contributor of fibrosis in several liver diseases (Gressner, Weiskirchen, Breitkopf, \& Dooley, 2002). In patients with chronic liver diseases, an increased in Tgf- $\beta$ s expression was observed. For example, high level of Tgf- $\beta$ s is found during hepatic fibrosis in patients with hepatitis B, Hepatitis C (Kirmaz et al., 2004). An increased level of Tgf- $\beta$ s was also detected in peripheral blood mononuclear cells of alcoholic cirrhosis patients (W. X. Chen et al., 2002). As their important functions in fibrotic liver diseases became more apparent, the level of Tgf- $\beta$ is considered as potential indicator for prognosis (Kirmaz et al., 2004).

The increased level of Tgf- $\beta$ s is thought to be derived from damaged hepatic epithelium as well as from stromal cells including hepatic Stellate Cells (HSC), portal fibroblasts and inflammatory cells. In fibrotic liver from patient with cystic fibrosis liver disease (CFLD), cholangiocytes was shown to be the main source of Tgf- $\beta$ s (Lewindon et al., 2002). A study of fibrotic liver from patients and animal model of cholestatic liver diseases indicated that mesenchymal cells and inflammatory cells predominantly expressed Tgf- $\beta$ s (Milani, Herbst, Schuppan, Stein, \& Surrenti, 1991). Additionally, High level of Tgf- $\beta$ s was reported in perisinusoidal cells of liver obtained from rodents exposed to hepatotoxic carbon tetrachloride (Czaja et al., 1989). The observations imply that a selective expression of Tgf- $\beta$ ligands might play a critical role in liver fibrosis and regeneration

Tgf- $\beta$ is best known for regulation of HSC in fibrotic liver disease. This notion is supported by various types of evidence from in vivo and in vitro studies. Following hepatocyte injury, Tgf- $\beta$ up-regulates expression of its receptors and plasminogen activator inhibitor type 1 (PAI-1) in HSC (Knittel et al., 1999; Rieder, Armbrust, Meyer zum Buschenfelde, \& Ramadori, 1993). While Tgf- $\beta$ was shown to inhibit quiescent HSC proliferation induced by platelet-derived growth factor (PDGF), Tgf- $\beta$ shows stimulatory effect on expansion of transdifferentiation of myofibroblasts (Dooley, Delvoux, Lahme, Mangasser-Stephan, \& Gressner, 2000). HSCs also respond to Tgf- $\beta$ by up-regulating type I collagen and Tissue inhibitor of Metalloproteinase- 1 and -2 (TIMP-1 and -2) (Herbst et al., 1997). These HSC respond to Tgf- $\beta$ is mediated by Smad3 signaling pathway. Smad3 was shown to mediate Alk5-mediated fibrogenic response of HSC thru the induction of collagen synthesis (Furukawa et al., 2003; Inagaki, Mamura, et al., 2001; Inagaki, Nemoto, et al., 2001; Schnabl et al., 2001; Seyhan et al., 2006). It has also been shown that Smad1 is involved in Tgf- $\beta$-induced fibrogenic response thru stimulation of inhibitor of DNA binding 1 (Id1). Study has shown that Id1 is necessary for Tgf- $\beta$-induced response and its overexpression is sufficient induce HSC activation (Wiercinska et al., 2006).

Moreover, Tgf- $\beta$-mediated HSC response is under a functional negative feedback regulation by Smad7.In activated HSCs obtained from fibrotic rodent livers and from in vitro stimulations, a strong R-Smad activation is 
observed whereas Smad7 expression is diminished (Dooley et al., 2000; Dooley, Delvoux, et al., 2001; Dooley, Streckert, Delvoux, \& Gressner, 2001; Liu et al., 2003; Stopa, Anhuf, et al., 2000; Stopa, Benes, Ansorge, Gressner, \& Dooley, 2000; Tahashi et al., 2002). These finding suggest that suppression of Smad7 induction might contribute to fully stimulated Tgf- $\beta$ signaling in HSC during the progression of hepatic fibrosis.

In addition to regulating fibrogenesis, Tgf- $\beta$ has been found to modulate inflammatory response. Tgf- $\beta$ have been implicated in systemic inflammation since increased Tgf- $\beta$ level was observed in sepsis (Marie, Cavaillon, \& Losser, 1996) and post-traumatic shock (Laun et al., 2003; Varedi, Jeschke, Englander, Herndon, \& Barrow, 2001) Tgf- $\beta$ has been found to promote inflammatory cytokines Tumor necrosis factor- $\alpha$ (TNF- $\alpha)$ (Chantry, Turner, Abney, \& Feldmann, 1989) and Interleukin-6 (IL-6) (Turner, Chantry, \& Feldmann, 1990). Transgenic mice over-expressing Tgf- $\beta$ were more susceptible to endotoxemia (Vodovotz et al., 1998). The phenotype was associated with increased LPS-induced inflammatory cytokine secretion by liver cells (Garcia-Lazaro et al., 2005). It has also been reported that ectopic expression of Tgf- $\beta$ increases the immune infiltration on the liver in mouse model of alcoholic liver disease (Preisegger et al., 1999). This reveals the pro-inflammatory effect of Tgf- $\beta$ in hepatocytes during pathogenesis of liver disease. Alternatively, it is also possible that Tgf- $\beta$ exhibits its effect thru the enhancement of Th17 response since it has been shown that Tgf- $\beta$ can act as differentiation factor for Th17 cell (Mangan et al., 2006; Veldhoen, Hocking, Atkins, Locksley, \& Stockinger, 2006) that plays an important role in various types of inflammatory diseases (Bettelli, Oukka, \& Kuchroo, 2007). Since chronic inflammation and fibrosis are well-known to be risk factors for tumorigenesis (Grivennikov \& Karin, 2010), an increased Tgf- $\beta$ activity in affected liver seems to favor the onset of HCC.

\section{Tgf- $\beta$ as Tumor Suppressor}

Results of cell culture experiments have revealed an importance of Tgf- $\beta$ in controlling hepatocyte behavior. Tgf- $\beta$ is shown to suppress growth-inducing activity of various growth factors such as hepatocyte growth factor (HGF), epidermal growth factor (EGF) or insulin(Hayashi \& Carr, 1985; Nakamura et al., 1985). This growth-suppressive effect of Tgf- $\beta$ depends on interaction between smad protein and Sp1 transcription factors leading to upregulation of cyclin-dependent kinase (CDK) inhibitor p21 (Moustakas \& Kardassis, 1998). Besides being anti-proliferative, members of Tgf- $\beta$ family of ligand were found to induce hepatocyte apoptosis (Oberhammer et al., 1991; Schwall et al., 1993; Yasuda et al., 1993).The pro-apoptotic property was shown to be mediated by enhanced expression of death-associated protein (DAP) kinase (Jang et al., 2002)and pre-apoptotic protein BIM (Ramesh et al., 2008). Tgf- $\beta$-mediated apoptosis is also involved death domain-associated protein (DAXX) that interacts with Fas receptor to induce the JNK activation (Perlman, Schiemann, Brooks, Lodish, \& Weinberg, 2001).

In primary tumor, Tgf- $\beta$ was found to have tumor-suppressive effects. This statement is supported by results from experiments using transgenic and knockout mouse models. One earlier report indicates that expression of dominant-negative mutant T $\beta$ RII resulted in enhanced susceptibility to chemically induced hepatocarcinogenesis (Kanzler et al., 2001). Similarly, reduced expression of TRRII promoted the development of hepatocellular carcinoma induced by diethylnitroamine (Im et al., 2001). The increased incidences of HCC in the TRRII-deficient mice is associated with decreased Tgf- $\beta$-induced inhibition of hepatocyte growth and reduced expression of cell cylcle inhibitor, p27 kip1 . In addition, it was shown that deletion of TRRII in hepatocytes leaded to increased proliferation up-regulation of Cdk2, Cyclin E and Cyclin A expression as well as down-regulation of Cdkn1a/p21 expression in HCC (Baek et al., 2010). These findings indicated tumor-suppressive effect of Tgf- $\beta$ in the liver during hepatocarcinogenesis

\section{Evidence for Tumor-Promoting Role of Tgf- $\beta$}

While Tumor-suppressive effects of Tgf- $\beta$ have been reported in the past decade, data from additional studies of mutant mice lacking T $\beta$ RII in hepatocytes have challenged this idea. Baek et al., reported that abrogation of T $\beta R I I$ did not increase frequency or number of cancerous lesions found in mice overexpressing Tgf- $\alpha$ (Baek et al., 2010). $\mathrm{Mu}$ and Coworker also showed that the lack of T $\beta$ RII did not promote diethylnitrosamine-induced hepatocarcinogenesis (Mu et al., 2016). These observations suggested that HCC cells might acquire resistance to its growth-inhibitory effect.

While the mechanism in which HCC uses to escape the tumor suppressive functions is still unknown, few speculations have offered to explain this effect so far. The study of HCC obtained from patient and rodent model of HCC showed that expression of T $\beta$ RII was significantly lower in tumors when compared with the surrounding normal hepatocytes (Im et al., 2001; Mamiya et al., 2010).The reduced T $\beta R I I$ expression was associated with larger tumor size, poor differentiation, poor vein invasion, intrahepatic metastasis and shorter recurrence-free survival. These studies suggested that HCC might gain resistance to anti-proliferative effect of Tgf- $\beta$ thru down-regulation of its receptor. It has also been shown that over-expression of oncogenic Ha-Ras suppressed 
Tgf- $\beta$-induced inhibition of cell growth in hepatocytes (Houck, Michalopoulos, \& Strom, 1989). Moreover, study showed activation EGFR signaling impaired cytostatic Tgf- $\beta$ activity in preneoplastic setting (Dooley \& ten Dijke, 2012; Murillo, del Castillo, Sanchez, Fernandez, \& Fabregat, 2005). These data indicated that decreased Tgf- $\beta$-responsiveness in hepatocytes was at least in part mediated by EGF and Ha-Ras.

An increasing number of studies suggest that activation of Tgf- $\beta$ promote HCC development. Transcriptome analysis of human HCC revealed that Tgf- $\beta$ was associated with larger tumors and poor prognosis (Hoshida et al., 2009). In $25 \%$ of all early HCC, there is an association between Tgf- $\beta$ signaling and expression of $\alpha$-fetoprotein (AFP) and EpCAM (Yamashita et al., 2008). Tgf- $\beta$ has been associated with increased T regulatory cells that provide immunosuppressive environment enabling tumor cells to escape immune response (Wolf, Sopper, Pircher, Gastl, \& Wolf, 2015). Tgf- $\beta$ was also shown to induce transformation of liver progenitor cells into tumor-initiating cells thru up-regulation of CD90 and CD133 expression (Majumdar et al., 2012; Wu et al., 2012). There is aaditional evidence obtained from genetic mouse models of HCC supporting the notion that Tgf- $\beta$ is a tumor promotor. It was shown that disruption of T $\beta$ RII reduces the formation of HCC in Tak1 knockout mice (Yang et al., 2013). Moreover, mutant mice lackin T $\beta R I I$ in hepatocytes have increased susceptibility to hepatocarcinogenesis induced by 553 loss (Morris et al., 2012).

It is becoming more evident that Tgf- $\beta$ signaling is associated with highly invasive tumor condition. The contribution of Tgf- $\beta$ in this stage of tumorigenesis was believed to be centered on the epithelial-to-mesenchymal transition (EMT) that is characterized by the loss of epithelial marker, such as, E-Cadherin and Cytokeratin, and by acquisition of fibroblast marker, such as, vimentin, collagen, fibronectin and $\alpha$-smooth muscle actin (Guarino, Tosoni, \& Nebuloni, 2009). It was shown that Tgf- $\beta$ up-regulated of Snail transcription factor and induce EMT in HCC (Giannelli, Bergamini, Fransvea, Sgarra, \& Antonaci, 2005). Inhibition of Tgf- $\beta$ signaling pathway was shown to up-regulated E-Cadherin and block migration and invasion of HCC cells (Dituri et al., 2013; Fransvea, Angelotti, Antonaci, \& Giannelli, 2008). In addition to acting as EMT-inducer, Tgf- $\beta$ was known to promote HCC growth via angiogenesis regulation (Fransvea, Mazzocca, Antonaci, \& Giannelli, 2009; Mazzocca, Fransvea, Lavezzari, Antonaci, \& Giannelli, 2009). Moreover, Tgf- $\beta$ was known to promote the cross-talk between tumor cells and stromal cells during tumor progression of HCC (Mazzocca et al., 2010).

\section{Summary}

Tgf- $\beta$ has been shown to regulate several key steps in HCC tumorigenesis including proliferation, cell survival, migration, ECM production, angiogenesis and EMT. In pre-cancerous stage, Tgf- $\beta$ seemed to make liver more susceptible to HCC development by enhancing HSC-mediated fibrosis and inflammation whereas it blocked malignant transformation of hepatocyte thru regulation of cell division and apoptosis. In certain neoplastic hepatocytes, an increasing rate of mutation in tumor cells leaded to activation of oncogenic gene that enabled tumor cells to escape the growth suppressive function of Tgf- $\beta$ and acquire tumor promoting effect. Reversal of cytostatic effect of Tgf- $\beta$ to tumor-promoting activity required up-regulation of secreting proteins and EMT-inducing factors that promote tumor environment. However, there are also evidence indicating that, in some situations, Tgf- $\beta$-mediated cytostatic activity was not disrupted and played an important role in suppressing HCC carcinogenesis. These finding suggest that one must be mindful in inhibiting Tgf- $\beta$ signaling pathway in chronic liver damage. While targeting Tgf- $\beta$ pathway may reduce fibrogenesis and inflammation, it may increase the risk of malignant transformation in hepatocytes with intact suppress function of Tgf- $\beta$. Future studies will aim to investigate the involvement of signaling molecules that modulate the cytostaic activity of Tgf- $\beta$ during the initial transformation of HCC.

\section{Acknowledgements}

I would like to give thank to Mr. Chupong Juttaviriyasagul for helpful discussion of manuscript.

\section{References}

Attisano, L., \& Wrana, J. L. (2002). Signal transduction by the TGF-beta superfamily. Science, 296(5573), 1646-1647. http://dx.doi.org/10.1126/science.1071809

Baek, J. Y., Morris, S. M., Campbell, J., Fausto, N., Yeh, M. M., \& Grady, W. M. (2010). TGF-beta inactivation and TGF-alpha overexpression cooperate in an in vivo mouse model to induce hepatocellular carcinoma that recapitulates molecular features of human liver cancer. Int J Cancer, 127(5), 1060-1071. http://dx.doi.org/ $10.1002 /$ ijc. 25127

Bettelli, E., Oukka, M., \& Kuchroo, V. K. (2007). T(H)-17 cells in the circle of immunity and autoimmunity. Nat Immunol, 8(4), 345-350. http://dx.doi.org/10.1038/ni0407-345 
Bissell, D. M. (2001). Chronic liver injury, TGF-beta, and cancer. Exp Mol Med, 33(4), 179-190. http://dx.doi.org/ 10.1038/emm.2001.31

Branton, M. H., \& Kopp, J. B. (1999). TGF-beta and fibrosis. Microbes Infect, 1(15), 1349-1365.

Chantry, D., Turner, M., Abney, E., \& Feldmann, M. (1989). Modulation of cytokine production by transforming growth factor-beta. J Immunol, 142(12), 4295-4300.

Chen, R., Huang, C., Morinelli, T. A., Trojanowska, M., \& Paul, R. V. (2002). Blockade of the effects of TGF-beta1 on mesangial cells by overexpression of Smad7. J Am Soc Nephrol, 13(4), 887-893.

Chen, W. X., Li, Y. M., Yu, C. H., Cai, W. M., Zheng, M., \& Chen, F. (2002). Quantitative analysis of transforming growth factor beta $1 \mathrm{mRNA}$ in patients with alcoholic liver disease. World J Gastroenterol, 8(2), 379-381.

Czaja, M. J., Weiner, F. R., Flanders, K. C., Giambrone, M. A., Wind, R., Biempica, L., \& Zern, M. A. (1989). In vitro and in vivo association of transforming growth factor-beta 1 with hepatic fibrosis. J Cell Biol, 108(6), 2477-2482.

Derynck, R., \& Zhang, Y. E. (2003). Smad-dependent and Smad-independent pathways in TGF-beta family signalling. Nature, 425(6958), 577-584. http://dx.doi.org/10.1038/nature02006

Dituri, F., Mazzocca, A., Fernando, J., Papappicco, P., Fabregat, I., De Santis, F., ... Giannelli, G. (2013). Differential Inhibition of the TGF-beta Signaling Pathway in HCC Cells Using the Small Molecule Inhibitor LY2157299 and the D10 Monoclonal Antibody against TGF-beta Receptor Type II. PLoS One, 8(6), e67109. http://dx.doi.org/10.1371/journal.pone.0067109

Dooley, S., Delvoux, B., Lahme, B., Mangasser-Stephan, K., \& Gressner, A. M. (2000). Modulation of transforming growth factor beta response and signaling during transdifferentiation of rat hepatic stellate cells to myofibroblasts. Hepatology, 31(5), 1094-1106. http://dx.doi.org/10.1053/he.2000.6126

Dooley, S., Delvoux, B., Streckert, M., Bonzel, L., Stopa, M., ten Dijke, P., \& Gressner, A. M. (2001). Transforming growth factor beta signal transduction in hepatic stellate cells via Smad2/3 phosphorylation, a pathway that is abrogated during in vitro progression to myofibroblasts. TGFbeta signal transduction during transdifferentiation of hepatic stellate cells. FEBS Lett, 502(1-2), 4-10.

Dooley, S., Streckert, M., Delvoux, B., \& Gressner, A. M. (2001). Expression of Smads during in vitro transdifferentiation of hepatic stellate cells to myofibroblasts. Biochem Biophys Res Commun, 283(3), 554-562. http://dx.doi.org/10.1006/bbrc.2001.4811

Dooley, S., \& ten Dijke, P. (2012). TGF-beta in progression of liver disease. Cell Tissue Res, 347(1), 245-256. http://dx.doi.org/10.1007/s00441-011-1246-y

Ebisawa, T., Fukuchi, M., Murakami, G., Chiba, T., Tanaka, K., Imamura, T., \& Miyazono, K. (2001). Smurf1 interacts with transforming growth factor-beta type I receptor through Smad7 and induces receptor degradation. J Biol Chem, 276(16), 12477-12480. http://dx.doi.org/10.1074/jbc.C100008200

Ferlay, J., Shin, H. R., Bray, F., Forman, D., Mathers, C., \& Parkin, D. M. (2010). Estimates of worldwide burden of cancer in 2008: GLOBOCAN 2008. Int J Cancer, 127(12), 2893-2917. http://dx.doi.org/10.1002/ijc.25516

Fransvea, E., Angelotti, U., Antonaci, S., \& Giannelli, G. (2008). Blocking transforming growth factor-beta up-regulates E-cadherin and reduces migration and invasion of hepatocellular carcinoma cells. Hepatology, 47(5), 1557-1566. http://dx.doi.org/10.1002/hep.22201

Fransvea, E., Mazzocca, A., Antonaci, S., \& Giannelli, G. (2009). Targeting transforming growth factor (TGF)-betaRI inhibits activation of betal integrin and blocks vascular invasion in hepatocellular carcinoma. Hepatology, 49(3), 839-850. http://dx.doi.org/10.1002/hep.22731

Furukawa, F., Matsuzaki, K., Mori, S., Tahashi, Y., Yoshida, K., Sugano, Y., ... Inoue, K. (2003). p38 MAPK mediates fibrogenic signal through Smad3 phosphorylation in rat myofibroblasts. Hepatology, 38(4), 879-889. http://dx.doi.org/10.1053/jhep.2003.50384

Garcia-Lazaro, J. F., Thieringer, F., Luth, S., Czochra, P., Meyer, E., Renteria, I. B., ... Kanzler, S. (2005). Hepatic over-expression of TGF-betal promotes LPS-induced inflammatory cytokine secretion by liver cells and endotoxemic shock. Immunol Lett, 101(2), 217-222. http://dx.doi.org/10.1016/j.imlet.2005.06.003 
Giannelli, G., Bergamini, C., Fransvea, E., Sgarra, C., \& Antonaci, S. (2005). Laminin-5 with transforming growth factor-betal induces epithelial to mesenchymal transition in hepatocellular carcinoma. Gastroenterology, 129(5), 1375-1383. http://dx.doi.org/10.1053/j.gastro.2005.09.055

Goumans, M. J., Valdimarsdottir, G., Itoh, S., Lebrin, F., Larsson, J., Mummery, C., . . ten Dijke, P. (2003). Activin receptor-like kinase (ALK)1 is an antagonistic mediator of lateral TGFbeta/ALK5 signaling. Mol Cell, 12(4), 817-828.

Gressner, A. M., Weiskirchen, R., Breitkopf, K., \& Dooley, S. (2002). Roles of TGF-beta in hepatic fibrosis. Front Biosci, 7, d793-807.

Grivennikov, S. I., \& Karin, M. (2010). Inflammation and oncogenesis: a vicious connection. Curr Opin Genet Dev, 20(1), 65-71. http://dx.doi.org/10.1016/j.gde.2009.11.004

Guarino, M., Tosoni, A., \& Nebuloni, M. (2009). Direct contribution of epithelium to organ fibrosis: epithelial-mesenchymal transition. Hum Pathol, 40(10), 1365-1376. http://dx.doi.org/10.1016/j.humpath. 2009.02.020

Hayashi, I., \& Carr, B. I. (1985). DNA synthesis in rat hepatocytes: inhibition by a platelet factor and stimulation by an endogenous factor. J Cell Physiol, 125(1), 82-90. http://dx.doi.org/10.1002/jcp.1041250111

Heldin, C. H., Miyazono, K., \& ten Dijke, P. (1997). TGF-beta signalling from cell membrane to nucleus through SMAD proteins. Nature, 390(6659), 465-471. http://dx.doi.org/10.1038/37284

Herbst, H., Wege, T., Milani, S., Pellegrini, G., Orzechowski, H. D., Bechstein, W. O., ... Schuppan, D. (1997). Tissue inhibitor of metalloproteinase-1 and -2 RNA expression in rat and human liver fibrosis. Am J Pathol, 150(5), 1647-1659.

Hoshida, Y., Nijman, S. M., Kobayashi, M., Chan, J. A., Brunet, J. P., Chiang, D. Y., ... Golub, T. R. (2009). Integrative transcriptome analysis reveals common molecular subclasses of human hepatocellular carcinoma. Cancer Res, 69(18), 7385-7392. http://dx.doi.org/10.1158/0008-5472.CAN-09-1089

Houck, K. A., Michalopoulos, G. K., \& Strom, S. C. (1989). Introduction of a Ha-ras oncogene into rat liver epithelial cells and parenchymal hepatocytes confers resistance to the growth inhibitory effects of TGF-beta. Oncogene, 4(1), 19-25.

Im, Y. H., Kim, H. T., Kim, I. Y., Factor, V. M., Hahm, K. B., Anzano, M., ... Kim, S. J. (2001). Heterozygous mice for the transforming growth factor-beta type II receptor gene have increased susceptibility to hepatocellular carcinogenesis. Cancer Res, 61(18), 6665-6668.

Inagaki, Y., Mamura, M., Kanamaru, Y., Greenwel, P., Nemoto, T., Takehara, K., ... Nakao, A. (2001). Constitutive phosphorylation and nuclear localization of Smad3 are correlated with increased collagen gene transcription in activated hepatic stellate cells. J Cell Physiol, 187(1), 117-123. http://dx.doi.org/10.1002/ 1097-4652(2001)9999:9999<00::AID-JCP1059>3.0.CO;2-S

Inagaki, Y., Nemoto, T., Nakao, A., Dijke, P., Kobayashi, K., Takehara, K., \& Greenwel, P. (2001). Interaction between GC box binding factors and Smad proteins modulates cell lineage-specific alpha 2(I) collagen gene transcription. J Biol Chem, 276(19), 16573-16579. http://dx.doi.org/10.1074/jbc.M010485200

Jang, C. W., Chen, C. H., Chen, C. C., Chen, J. Y., Su, Y. H., \& Chen, R. H. (2002). TGF-beta induces apoptosis through Smad-mediated expression of DAP-kinase. Nat Cell Biol, 4(1), 51-58. http://dx.doi.org/10. $1038 /$ ncb731

Kanzler, S., Meyer, E., Lohse, A. W., Schirmacher, P., Henninger, J., Galle, P. R., \& Blessing, M. (2001). Hepatocellular expression of a dominant-negative mutant TGF-beta type II receptor accelerates chemically induced hepatocarcinogenesis. Oncogene, 20(36), 5015-5024. http://dx.doi.org/10.1038/sj.onc.1204544

Kirmaz, C., Terzioglu, E., Topalak, O., Bayrak, P., Yilmaz, O., Ersoz, G., \& Sebik, F. (2004). Serum transforming growth factor-beta1(TGF-beta1) in patients with cirrhosis, chronic hepatitis B and chronic hepatitis $\mathrm{C}$ [corrected]. Eur Cytokine Netw, 15(2), 112-116.

Knittel, T., Kobold, D., Saile, B., Grundmann, A., Neubauer, K., Piscaglia, F., \& Ramadori, G. (1999). Rat liver myofibroblasts and hepatic stellate cells: different cell populations of the fibroblast lineage with fibrogenic potential. Gastroenterology, 117(5), 1205-1221.

Kowdley, K. V. (2004). Iron, hemochromatosis, and hepatocellular carcinoma. Gastroenterology, 127(5 Suppl 1), S79-86. 
Kumagi, T., Horiike, N., Michitaka, K., Hasebe, A., Kawai, K., Tokumoto, Y., . . Onji, M. (2004). Recent clinical features of Wilson's disease with hepatic presentation. $J$ Gastroenterol, 39(12), 1165-1169. http://dx.doi.org/10.1007/s00535-004-1466-y

Laun, R. A., Schroder, O., Schoppnies, M., Roher, H. D., Ekkernkamp, A., \& Schulte, K. M. (2003). Transforming growth factor-betal and major trauma: time-dependent association with hepatic and renal insufficiency. Shock, 19(1), 16-23.

Lewindon, P. J., Pereira, T. N., Hoskins, A. C., Bridle, K. R., Williamson, R. M., Shepherd, R. W., \& Ramm, G. A. (2002). The role of hepatic stellate cells and transforming growth factor-beta(1) in cystic fibrosis liver disease. Am J Pathol, 160(5), 1705-1715.

Liu, C., Gaca, M. D., Swenson, E. S., Vellucci, V. F., Reiss, M., \& Wells, R. G. (2003). Smads 2 and 3 are differentially activated by transforming growth factor-beta (TGF-beta) in quiescent and activated hepatic stellate cells. Constitutive nuclear localization of Smads in activated cells is TGF-beta-independent. $J$ Biol Chem, 278(13), 11721-11728. http://dx.doi.org/10.1074/jbc.M207728200

Majumdar, A., Curley, S. A., Wu, X., Brown, P., Hwang, J. P., Shetty, K., ... Mishra, L. (2012). Hepatic stem cells and transforming growth factor beta in hepatocellular carcinoma. Nat Rev Gastroenterol Hepatol, 9(9), 530-538. http://dx.doi.org/10.1038/nrgastro.2012.114

Mamiya, T., Yamazaki, K., Masugi, Y., Mori, T., Effendi, K., Du, W., ... Sakamoto, M. (2010). Reduced transforming growth factor-beta receptor II expression in hepatocellular carcinoma correlates with intrahepatic metastasis. Lab Invest, 90(9), 1339-1345. http://dx.doi.org/10.1038/labinvest.2010.105

Mangan, P. R., Harrington, L. E., O'Quinn, D. B., Helms, W. S., Bullard, D. C., Elson, C. O., ... Weaver, C. T. (2006). Transforming growth factor-beta induces development of the $\mathrm{T}(\mathrm{H}) 17$ lineage. Nature, 441(7090), 231-234. http://dx.doi.org/10.1038/nature04754

Marie, C., Cavaillon, J. M., \& Losser, M. R. (1996). Elevated levels of circulating transforming growth factor-beta 1 in patients with the sepsis syndrome. Ann Intern Med, 125(6), 520-521.

Massague, J., \& Chen, Y. G. (2000). Controlling TGF-beta signaling. Genes Dev, 14(6), 627-644.

Mazzocca, A., Fransvea, E., Dituri, F., Lupo, L., Antonaci, S., \& Giannelli, G. (2010). Down-regulation of connective tissue growth factor by inhibition of transforming growth factor beta blocks the tumor-stroma cross-talk and tumor progression in hepatocellular carcinoma. Hepatology, 51(2), 523-534. http://dx.doi.org/10.1002/hep.23285

Mazzocca, A., Fransvea, E., Lavezzari, G., Antonaci, S., \& Giannelli, G. (2009). Inhibition of transforming growth factor beta receptor I kinase blocks hepatocellular carcinoma growth through neo-angiogenesis regulation. Hepatology, 50(4), 1140-1151. http://dx.doi.org/10.1002/hep.23118

Milani, S., Herbst, H., Schuppan, D., Stein, H., \& Surrenti, C. (1991). Transforming growth factors beta 1 and beta 2 are differentially expressed in fibrotic liver disease. Am J Pathol, 139(6), 1221-1229.

Morris, S. M., Baek, J. Y., Koszarek, A., Kanngurn, S., Knoblaugh, S. E., \& Grady, W. M. (2012). Transforming growth factor-beta signaling promotes hepatocarcinogenesis induced by p53 loss. Hepatology, 55(1), 121-131. http://dx.doi.org/10.1002/hep.24653

Moustakas, A., \& Kardassis, D. (1998). Regulation of the human p21/WAF1/Cip1 promoter in hepatic cells by functional interactions between Sp1 and Smad family members. Proc Natl Acad Sci U S A, 95(12), 6733-6738.

Mu, X., Pradere, J. P., Affo, S., Dapito, D. H., Friedman, R., Lefkovitch, J. H., \& Schwabe, R. F. (2016). Epithelial Transforming Growth Factor-beta Signaling Does Not Contribute to Liver Fibrosis but Protects Mice From Cholangiocarcinoma. Gastroenterology, 150(3), 720-733. http://dx.doi.org/10.1053/j.gastro.2015.11.039

Murillo, M. M., del Castillo, G., Sanchez, A., Fernandez, M., \& Fabregat, I. (2005). Involvement of EGF receptor and c-Src in the survival signals induced by TGF-betal in hepatocytes. Oncogene, 24(28), 4580-4587. http://dx.doi.org/10.1038/sj.onc.1208664

Nakamura, T., Tomita, Y., Hirai, R., Yamaoka, K., Kaji, K., \& Ichihara, A. (1985). Inhibitory effect of transforming growth factor-beta on DNA synthesis of adult rat hepatocytes in primary culture. Biochem Biophys Res Commun, 133(3), 1042-1050. 
Nakao, A., Afrakhte, M., Moren, A., Nakayama, T., Christian, J. L., Heuchel, R., ... ten Dijke, P. (1997). Identification of Smad7, a TGFbeta-inducible antagonist of TGF-beta signalling. Nature, 389(6651), 631-635. http://dx.doi.org/10.1038/39369

Nordenstedt, H., White, D. L., \& El-Serag, H. B. (2010). The changing pattern of epidemiology in hepatocellular carcinoma. Dig Liver Dis, 42 Suppl 3, S206-214. http://dx.doi.org/10.1016/S1590-8658(10)60507-5

O'Donnell, D. H., Ryan, R., Hayes, B., Fennelly, D., \& Gibney, R. G. (2009). Hepatocellular carcinoma complicating cystic fibrosis related liver disease. $J$ Cyst Fibros, 8(4), 288-290. http://dx.doi.org/10.1016/j.jcf.2009.05.002

Oberhammer, F., Bursch, W., Parzefall, W., Breit, P., Erber, E., Stadler, M., \& Schulte-Hermann, R. (1991). Effect of transforming growth factor beta on cell death of cultured rat hepatocytes. Cancer Res, 51(9), 2478-2485.

Perlman, R., Schiemann, W. P., Brooks, M. W., Lodish, H. F., \& Weinberg, R. A. (2001). TGF-beta-induced apoptosis is mediated by the adapter protein Daxx that facilitates JNK activation. Nat Cell Biol, 3(8), 708-714. http://dx.doi.org/10.1038/35087019

Piek, E., Heldin, C. H., \& Ten Dijke, P. (1999). Specificity, diversity, and regulation in TGF-beta superfamily signaling. FASEB J, 13(15), 2105-2124.

Preisegger, K. H., Factor, V. M., Fuchsbichler, A., Stumptner, C., Denk, H., \& Thorgeirsson, S. S. (1999). Atypical ductular proliferation and its inhibition by transforming growth factor betal in the 3,5-diethoxycarbonyl-1,4-dihydrocollidine mouse model for chronic alcoholic liver disease. Lab Invest, 79(2), 103-109.

Ramesh, S., Qi, X. J., Wildey, G. M., Robinson, J., Molkentin, J., Letterio, J., \& Howe, P. H. (2008). TGF beta-mediated BIM expression and apoptosis are regulated through SMAD3-dependent expression of the MAPK phosphatase MKP2. EMBO Rep, 9(10), 990-997. http://dx.doi.org/10.1038/embor.2008.158

Rieder, H., Armbrust, T., Meyer zum Buschenfelde, K. H., \& Ramadori, G. (1993). Contribution of sinusoidal endothelial liver cells to liver fibrosis: expression of transforming growth factor-beta 1 receptors and modulation of plasmin-generating enzymes by transforming growth factor-beta 1. Hepatology, 18(4), 937-944.

Schnabl, B., Kweon, Y. O., Frederick, J. P., Wang, X. F., Rippe, R. A., \& Brenner, D. A. (2001). The role of Smad3 in mediating mouse hepatic stellate cell activation. Hepatology, 34(1), 89-100. http://dx.doi.org/10.1053/jhep.2001.25349

Schwall, R. H., Robbins, K., Jardieu, P., Chang, L., Lai, C., \& Terrell, T. G. (1993). Activin induces cell death in hepatocytes in vivo and in vitro. Hepatology, 18(2), 347-356.

Seyhan, H., Hamzavi, J., Wiercinska, E., Gressner, A. M., Mertens, P. R., Kopp, J., . . Dooley, S. (2006). Liver fibrogenesis due to cholestasis is associated with increased Smad7 expression and Smad3 signaling. $J$ Cell Mol Med, 10(4), 922-932.

Shi, W., Sun, C., He, B., Xiong, W., Shi, X., Yao, D., \& Cao, X. (2004). GADD34-PP1c recruited by Smad7 dephosphorylates TGFbeta type I receptor. $J$ Cell Biol, 164(2), 291-300. http://dx.doi.org/10.1083/jcb.200307151

Shi, Y., \& Massague, J. (2003). Mechanisms of TGF-beta signaling from cell membrane to the nucleus. Cell, 113(6), 685-700.

Stopa, M., Anhuf, D., Terstegen, L., Gatsios, P., Gressner, A. M., \& Dooley, S. (2000). Participation of Smad2, Smad3, and Smad4 in transforming growth factor beta (TGF-beta)-induced activation of Smad7. THE TGF-beta response element of the promoter requires functional Smad binding element and E-box sequences for transcriptional regulation. $J$ Biol Chem, 275(38), 29308-29317. http://dx.doi.org/10.1074/jbc. M003282200

Stopa, M., Benes, V., Ansorge, W., Gressner, A. M., \& Dooley, S. (2000). Genomic locus and promoter region of rat Smad7, an important antagonist of TGFbeta signaling. Mamm Genome, 11(2), 169-176.

Tahashi, Y., Matsuzaki, K., Date, M., Yoshida, K., Furukawa, F., Sugano, Y., ... Inoue, K. (2002). Differential regulation of TGF-beta signal in hepatic stellate cells between acute and chronic rat liver injury. Hepatology, 35(1), 49-61. http://dx.doi.org/10.1053/jhep.2002.30083

ten Dijke, P., \& Hill, C. S. (2004). New insights into TGF-beta-Smad signalling. Trends Biochem Sci, 29(5), 265-273. http://dx.doi.org/10.1016/j.tibs.2004.03.008 
Turner, M., Chantry, D., \& Feldmann, M. (1990). Transforming growth factor beta induces the production of interleukin 6 by human peripheral blood mononuclear cells. Cytokine, 2(3), 211-216.

Varedi, M., Jeschke, M. G., Englander, E. W., Herndon, D. N., \& Barrow, R. E. (2001). Serum TGF-beta in thermally injured rats. Shock, 16(5), 380-382.

Veldhoen, M., Hocking, R. J., Atkins, C. J., Locksley, R. M., \& Stockinger, B. (2006). TGFbeta in the context of an inflammatory cytokine milieu supports de novo differentiation of IL-17-producing T cells. Immunity, 24(2), 179-189. http://dx.doi.org/10.1016/j.immuni.2006.01.001

Vodovotz, Y., Kopp, J. B., Takeguchi, H., Shrivastav, S., Coffin, D., Lucia, M. S., ... Roberts, A. B. (1998). Increased mortality, blunted production of nitric oxide, and increased production of TNF-alpha in endotoxemic TGF-beta1 transgenic mice. J Leukoc Biol, 63(1), 31-39.

von Gersdorff, G., Susztak, K., Rezvani, F., Bitzer, M., Liang, D., \& Bottinger, E. P. (2000). Smad3 and Smad4 mediate transcriptional activation of the human Smad7 promoter by transforming growth factor beta. $J$ Biol Chem, 275(15), 11320-11326.

Wiercinska, E., Wickert, L., Denecke, B., Said, H. M., Hamzavi, J., Gressner, A. M., ... Dooley, S. (2006). Id1 is a critical mediator in TGF-beta-induced transdifferentiation of rat hepatic stellate cells. Hepatology, 43(5), 1032-1041. http://dx.doi.org/10.1002/hep.21135

Wolf, D., Sopper, S., Pircher, A., Gastl, G., \& Wolf, A. M. (2015). Treg(s) in Cancer: Friends or Foe? J Cell Physiol, 230(11), 2598-2605. http://dx.doi.org/10.1002/jcp.25016

Wu, K., Ding, J., Chen, C., Sun, W., Ning, B. F., Wen, W., ... Wang, H. Y. (2012). Hepatic transforming growth factor beta gives rise to tumor-initiating cells and promotes liver cancer development. Hepatology, 56(6), 2255-2267. http://dx.doi.org/10.1002/hep.26007

Yamashita, T., Forgues, M., Wang, W., Kim, J. W., Ye, Q., Jia, H., ... Wang, X. W. (2008). EpCAM and alpha-fetoprotein expression defines novel prognostic subtypes of hepatocellular carcinoma. Cancer Res, 68(5), 1451-1461. http://dx.doi.org/10.1158/0008-5472.CAN-07-6013

Yang, L., Inokuchi, S., Roh, Y. S., Song, J., Loomba, R., Park, E. J., \& Seki, E. (2013). Transforming growth factor-beta signaling in hepatocytes promotes hepatic fibrosis and carcinogenesis in mice with hepatocyte-specific deletion of TAK1. Gastroenterology, 144(5), 1042-1054 e1044. http://dx.doi.org/10. 1053/j.gastro.2013.01.056

Yasuda, H., Mine, T., Shibata, H., Eto, Y., Hasegawa, Y., Takeuchi, T., ... Kojima, I. (1993). Activin A: an autocrine inhibitor of initiation of DNA synthesis in rat hepatocytes. J Clin Invest, 92(3), 1491-1496. http://dx.doi.org/10.1172/JCI116727

Zhao, J., Shi, W., Chen, H., \& Warburton, D. (2000). Smad7 and Smad6 differentially modulate transforming growth factor beta -induced inhibition of embryonic lung morphogenesis. J Biol Chem, 275(31), 23992-23997. http://dx.doi.org/10.1074/jbc.M002433200

\section{Copyrights}

Copyright for this article is retained by the author(s), with first publication rights granted to the journal.

This is an open-access article distributed under the terms and conditions of the Creative Commons Attribution license (http://creativecommons.org/licenses/by/4.0/). 